\title{
Model Komunikasi Bisnis Jual Beli Buku Melalui Komunikasi Interpersonal dan Komunitas Grup Facebook
}

\author{
Iswahyu Pranawukir ${ }^{1}$, Maria Jashinta Elisabet Hamboer ${ }^{2}$ \\ 1,2Institut Bisnis dan Informatika Kosgoro 1957 \\ Jalan Moch Kahfi II No.33, Lenteng Agung Jakarta Selatan \\ E-mail : prana1enator@gmail.com¹, jashinta12@yahoo.com²
}

\begin{abstract}
ABSTRAK
Transaksi jual beli terjadi akibat adanya pertukaran pesan dan informasi dalam pemenuhan kebutuhan manusia juga dapat dikatakan sebagian dari aktifitas manusia dalam berkomunikasi bisnis. Komunikasi bisnis telah merambah setiap bidang termasuk didalam jual beli buku secara online termasuk media sosial Facebook. Penelitian ini ingin mengetahui model komunikasi bisnis yang dilancarkan oleh penjual buku sebagai komunikator dan pembeli buku sebagai komunikan disertai Facebook sebagai media pemasaran. Berdasarkan hasil penelitian berupa observasi non partisipan ataupun partisipan yang diketahui buku yang dijual beli online dibagi secara garis besar menjadi tiga kategori jenis yaitu buku baru (cetakan baru/teks ajar), buku bekas (seken/tekspelajaran), buku langka/antik (antique/rare). Sedangkan berdasarkan hasil wawancara secara mendalam bahwa model komunikasi bisnis serta pemasaran melalui Facebook dapat dikatakan masing-masing penjual dan pembeli buku memanfaatkan jejaring pertemanan (friendlist) secara komunikasi interpersonal dan komunikasi kelompok (komunitas grup ) yang memiliki kesamaan hobi mengkoleksi kedua kategori jenis buku diatas secara mutualfriend. Secara berjejaring sosial setiap anggota pertemanan atau komunitas grup hidup berdampingan dalam komunikasi bisnis dengan menerapkan strategi postingan berupa foto dalam menawarkan buku melalui judul, dan kesamaan hobby untuk mengkoleksi buku untuk diperjual-belikan kembali,sedangkan tema yang kerap dicari dan tampil laku pada wall postingan penjual buku adalah buku tentang : Pramoedya Ananta Toer (PAT) kategori sastra, ideologi (buku kiri), militer, sejarah, agama, politik, ekonomi,hukum, sosial dan budaya serta buku bacaan hobi seperti : komik dan novel.
\end{abstract}

Kata kunci : model komunikasi, bisnis buku, komunikasi interpersonal, komunitas grup

\begin{abstract}
An online transaction activities are involving exchange of messages and information. This is actually part human activities in order to fulfill the human's need which is also part of what socalled business communication. Business communication itself has been improved and developed in many fields in recent years. Selling books online and using the social media platform such as Facebook is one of them. This study aims to study the business communication model of selling books using particularly the social media platform of Facebook as a medium. In this context, the sellers play a role as the communicators while the buyers in the position of communicants. Through both method of non-participatory and participatory observations, this study shows there are three categories of mainly books that sold online. First is the brand new books (new prints/new text books), second is the used books (known as the secondhand books) and the third is what so called the collectable, rare and antique books. Using an in-depth interview for analysing business communication model and marketing strategies of selling books online in Facebook, it is evidence that both sellers and buyers have been using and optimilising their networks of friendship through their friend list contacts, both for their interpersonal as well as community communications. They
\end{abstract}


utilise the communications among book lovers and book collectors as the most important strategy of their marketing approach. Therefore, it is clear that both personal and social networking are existed side by side in this social media context for the purpose of their business communication. When someone selling a book online in Facebook, they normally would post the image or photo detailing the book which can be seen by all contacts in their networks including those book lovers or book collectors who often would re-sell their book again online, by using the same social media networks. This research also shows that there are only certain kind of books that mostly sought after by people who use online book selling networks in Facebook. This information comes from contents mainly collected from the wall of Facebook. The list of most popular and top selling books are quite long. Any works by the famous Indonesian writer Pramoedya Ananta Toer (PAT) are the most popular ones. People are also looking for books on literature, the leftist, military, history, religion, politics, economics, law, social and cultural issues. Leisure books such as comics and novels are also selling well.

Keywords: communication model, business books, interpersonal communication, group community..

\section{PENDAHULUAN}

Setiap manusia pasti berkomunikasi, secara umum cara berkomunikasi dapat dimaknai dengan adanya pertukaran informasi atau pertukaran pesan yang dilakukan oleh dua orang atau lebih dalam berinteraksi. Apakah itu dilakukan seorang komunikator kepada komunikan? ataupun sebaliknya? Definisi komunikasi ini dapat dipastikan telah terjadi interaksi dalam konteks diadic communication atau berkomunikasi dengan kelompok (out group dan in group)

Dalam komunikasi bisnis terjadi pula komunikasi dalam bentuk pertukaran ide, simbol, makna verbal atau non verbal maupun bentuk transaksi. Adapun dalam komunikasi bisnis terdapat 3 (tiga) tujuan: memberikan informasi (informing), membujuk (persuasing), melakukan Kerjasama atau kolaborasi (Fatimah \& Nuryaningsih, 2018)

Tidak hanya dalam berbisnis secara konvensional, komunikasi bisnis yang mengikuti kekinian juga dimaknai dengan bisnis jual beli secara online. Hal yang umum ialah dilakukan strategi pemasarannya melalui media sosial selain mudah dalam penggunaannya, tak berbayar juga bisa menawarkan produknya melalui bisnis iklan yang telah disediakan

Jual beli online semakin hari semakin semarak apalagi sejak kehadiran internet yang menghadirkan jagat maya digitalisasi, new media (media baru) seperti tak mengenal batasan wilayah lagi sehingga setiap orang atau perusahaan mampu menghiasi konten jual dan beli yang ditawarkan melalui media sosial seperti melalui: facebook, twiter, Instagram, Tik Tok.

Dalam media sosial Facebook terdapat tampilan profil dimana setiap pengguna (user) dapat menambah pertemanan, menyimpan dengan mengupload foto, berbagi hobby dan minat, dan terkoneksi dengan orang lain baik yang telah dikenal sebelumnya maupun teman yang baru dikenal, selain daripada itu Facebook menawarkan pula visualisasi jaringan dari hubungan pengguna dengan menggunakan facebook groups.

Grup-grup ada didalamnya juga membentuk jaringan komunitas pertemanan didalamnya. Hampir sama ketika seorang pengguna men-setting pada profil Facebook-nya. Siapapun setiap pengguna dapat membuat grup sendiri atau dapat memilih untuk bergabung kedalam suatu grup yang dikehendaki di Facebook sendiri dengan 
salah satu dari tiga tingkat akses yang berbeda:(1)Buka-Siapapun dapat bergabung.(2)Ditutup - Siapapun harus meminta untuk bergabung dengan Grup, dan harus disetujui oleh administrator pada grup tersebut. (3)Rahasia - Siapaun harus diundang ke dalam Grup, dan Grup tidak muncul dalam pencarian apa pun(Levy, 2010)

Komunikasi bisnis di Facebook dapat dikategorikan memiliki model komunikasi bisnis konsep interaksi diadic communication dipadukan dengan model interaksi didalam kelompok (in group) untuk menciptakan ruang-ruang publik dan ruang-ruang khusus (privacy) tersendiri serta sebagai konsep ajang interaksi tidak hanya untuk eksistensi diri saja melainkan pula model pengembangan hubungan antar sosial bermasyarakat tanpa membatasi proses komunikasi yang berlangsung

Batasan komunikasi sebagai proses interaksi, yang menyamakan komunikasi dengan proses sebab-akibat atau aksireaksi yang telah ada faktor umpan balik (feedback). Interaksi ini sangat tergantung pada arah saat seseorang menyampaikan pesan, baik verbal atau nonverbal (Bahfiarti, 2012)

Sehingga interaksi sosial dijadikan proses komunikasi penuh dengan konsep kesadaran dimana konsep tersebut diperkenalkan konsep 'Dasein' atau berada di sana (being there) yang menunjuk pada dunia yang dialami (being in the world). Setiap pengalaman memiliki arti tertentu dan sangat khusus.

Dari pengalaman-pengalaman berkomunikasi maka timbulah fenomenafenomena yang disebut dengan gejala itulah konsep kesadaran dalam kegiatan jual beli di media sosial dijadikan pijakan peneliti untuk meneliti model interaksi komunikasi bisnis jual-beli buku pada Facebook dalam tataran komumikasi interpersonal (antar pribadi) dan komunikasi kelompok

\section{METODOLOGI}

Metodologi yang digunakan dalam penelitian ini kualitatif dengan pendekatan fenomenologi. Menurut Edmund Husserl pemahaman kita tentang fenomena timbul karena adanya kesadaran (consciousness) akan gejalagejala yang ada dalam realitas sosial. Kesadaran akan sesuatu hanya mungkin terjadi karena adanya keterarahan (intentionality) pada gejala yang hendak diteliti oleh peneliti.

Fenomenologi mempelajari strukur pengalaman dan kesadaran. Secara harfiah, fenomenologi adalah studi yang mempelajari, penampakan, segala yang muncul dalam pengalaman kita, cara kita mengalami sesuatu, dan makna yang kita miliki dalam pengalaman kita. Atau pengalaman sadar dari sudut pandang orang pertama (yang mengalaminya secara langsung). (Kuswarno, 2009: 22) dalam (Susanti \& Kholisoh, 2018)

Namun, menurut Bertens (1981;9) dalam (Hasbiansyah, 2008) bahwa pendekatan fenomenologi adalah sebagai suatu analisis deskriptif kualitatif serta introspektif mengenai kedalaman dari semua bentuk kesadaran dan pengalaman langsung.

Sehingga kaitannya dengan penjelasan diatas peneliti menyadari sepenuhnya realitas eksternal sebagai hal yang benar-benar nyata tetapi fenomena model komunikasi bisnis jual beli buku hanya bisa dipahami melalui kesadaran yang peneliti adopsi dari para penjual dan pembeli buku secara online di Facebook dalam pemikiran peneliti secara subyektif menjadi obyektif

Penelitian kualitatif diartikel ini menekankan pada tahapan-tahapan perumusan masalah, tujuan, pengumpulan data, dan analisis data yang tidak dapat dipisahkan. Analisis data dilakukan secara simultan oleh kedua peneliti dengan menggunakan bentuk proses penajaman masalah, tujuan, dan teknik pengumpulan datanya. Hal ini dilakukan peneliti untuk 
memulai penelitiannya dari suatu masalah yang diramalkan (foreshadowed problems) yang akan dimodifikasi serta dipertajam sesuai dengan temuan-temuan penelitian di lapangan. Dengan mengobservasi 20 (dua puluh ) masingmasing akun penjual dan akun pembeli dan mewawancarai 10 (sepuluh) orang masing-masing penjual dan pembeli buku yang telah memiliki akun Facebook minimal 1 (satu) tahun terakhir

Tujuan metode ini adalah menangkap arti pengalaman hidup manusia tentang suatu gejala. Metode fenomenologi hendak mengetahui lebih jauh struktur kesadaran dalam pengalaman manusia (Raco, 2018), utamanya saat melancarkan interaksi memperjual-belikan buku di Facebook

Dibawah ini adalah gambaran tahapan-tahapan yang dilaksanakan dalam penelitian ini

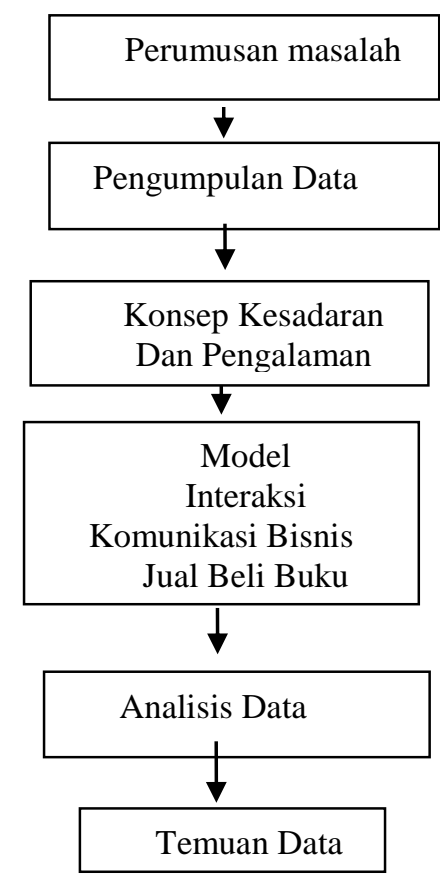

\section{LANDASAN TEORI}

\section{Komunikasi Interpersonal}

Komunikasi interpersonal atau komunikasi antar pribadi merupakan proses yang melibatkan seorang komunikator (pemberi pesan) dan komunikan (penerima pesan) dan berlangsung secara diadik saling bertukar informasi, bertukar makna hingga menggunakan perasaan.

Dalam sudut pandang komunikasi interpersonal memainkan sisi-sisi pandangan secara pendekatan humanistik, yang fokus pada: keterbukaan, empati, sikap mendukung, dan kualitas- kualitas lain yang menciptakan interaksi yang bermakna jujur, dan memuaskan (DeVito, 1997:259 dalam (Kertamukti, 2013)).

\section{Komunikasi Kelompok}

Komunikasi kelompok berasal dari dari dua padanan kata, yaitu komunikasi dan kelompok. Komunikasi dalam bahasa Inggris : "communication" adopsi dari kata latin communicatio, dan bersumber dari kata communis yang berarti sama, yakni maksudnya menyamakan suatu makna. Sedangkan kelompok (Hariadi, 2011) kelompok dapat dipandang dari beragam pengertian : persepsi, motivasi, hingga tujuan, interdependensi, dan juga dari segi interaksi.

Berarti komunikasi kelompok adalah menyamakan suatu makna didalam suatu kelompok. Pengertian kelompok berdasarkan diatas dapat diartikan atas dasar: a) Motivasi dikemukakan Bass dalam(Tutiasri, 2016) yang mengemukakan bahwa suatu kelompok didefinisikan sekumpulan individu yang keberadaannya sebagai kumpulan memberikan reward kepada individuindividu. b) Atas dasar tujuan yang dikemukakan oleh Mills, kelompok dipandang Mills adalah suatu kesatuan yang terdiri atas dua orang atau lebih yang melakukan kontak hubungan untuk suatu 
tujuan tertentu. c) Segi interdependensi, mengatakan bahwa kelompok adalah sekumpulan orang yang saling bergantung satu dengan yang lainya. d) Dasar interaksi bahwa kelompok adalah dua orang atau lebih yang berinteraksi satu dengan tujuan masing-masing saling mempengaruhi.

\section{Komunikasi Bisnis}

Komunikasi bisnis adalah mengenai dua padanan kata yakni, komunikasi dan bisnis. Komunikasi ada proses pengiriman atau pengoperan pesan dari komunikator ke komunikan melalui saluran media dan terdapat efek respon atau tanggapan. Jika memandang bisnis dan komunikasi adalah sama-sama suatu proses sosial, dimana muaranya kita akan mengambil suatukesimpulan bahwa komunikasi adalah bisnis dan, sebaliknya. bisnis adalah komunikasi.

Artinya, pada setiap tingkatan terdapat gejala [fenomena], antara komunikasi dan bisnis merupakan gejala yang terintegrasi. Tidak bisa dipisahpisahkan. (Pandjaitan, 2016)

Bisnis sebagai hasil dari pengalaman aktual atau interaksi dengan merek, produk, atau layanan, pelanggan pasti akan memiliki beragam informasi spesifik tentang proses bisnis. Mungkin satu atau dua ide tentang bagaimana bisnis dapat melayani mereka dengan lebih baik di masa depan.(Evans, 2010)

\section{Facebook}

Facebook, Inc adalah sosial media online asal Amerika dan juga perusahaan jejaring sosial berbasis di Menlo, California, AS. Facebook sebagai media sosial yang cukup ngetrend merupakan besutan Mark Zuckerberg dan teman teman di asrama kuliahnya di Universitas Harvard yaitu Eduardo Saverin, Andrew Mc Collum, Dustin Moskowitz dan Chris Hughe ( sumber : sejarahlengkap.com).
Facebook diluncurkan dan, pada awalnya, hanya tersedia bagi mahasiswa Universitas Harvard. Pada bulan Maret 2004, hanya satu bulan setelah peluncuran awal, Zuckerberg memperluas akses ke Stanford, Yale, dan Columbia. Kemudian Zuckerberg dengan cepat memperluas akses ke semua universitas Ivy League, kemudian di sebelah universitas dan perguruan tinggi wilayah Boston, dan kemudian di seluruh Amerika Serikat dan Kanada.(Levy, 2010)

Seiring berjalannya waktu dari sisi akademis banyak hasil penelitian yang memberi petunjuk bahwa facebook tidak hanya berperan sebagai media promosi dalam bisnis online saja , tetapi juga berperan sebagai media untuk berkomunikasi dengan calon pembeli atau customer. Selain itu facebook mampu menciptakan pangsa pasar yang luas bagi pelaku bisnis online. Hal ini tentu memberikan dampak tersendiri terhadap hasil penjualan.(Gemilang, 2011)

Dikarenakan terdapat keterangan mutual friends di Facebook untuk menunjukkan pengguna lain yang dihubungkan melalui teman bersama tetapi yang belum terhubung secara langsung sehingga pengguna bisa mengembangkan hubungan dengan jaringan dari orang-orang pertemanan terdekat.

\section{HASIL DAN PEMBAHASAN}

Dari hasil penelitian yang didapatkan kedua peneliti bahwa dalam jual beli buku di Facebook. Terdapat hal yang harus diperhatikan para pedagang buku, pengkoleksi buku atau toko buku dalam melancarkan komunikasi bisnis online-nya melalui Facebook dengan penting sangat memperhatikan :

\section{Mutual Friends ( Teman Bersama)}

Mayoritas pengguna Facebook dalam hal jual beli buku secara online memanfaatkan keterangan mutual friend 
untuk menambahnya sebagai teman baru dalam membangun jaringan bersama pertemanan atau menambah customer atau calon pelanggan baru. Tujuan tidak lain untuk membangun dan membentuk jaringan pelanggan atau membangun jaringan para pengkoleksi buku yang ada di jaringannya masing-masing melalui postingan judul buku yang telah diuploadnya melalui : foto, tambah cerita, atau video, bahkan live video .

Dalam hal ini facebook berperan tak hanya berfungsi sebagai media promosi untuk berkomunikasi dengan calon pembeli atau customer sesuai dengan hobi judul dan keminatannya melalui postingan judul-judul buku saja. Melalui pertemanan ini mereka saling berinteraksi menggunakan chatting atau percakapan online diantara penggunanya untuk membahas buku yang telah ditawarkannya melalui postingan judul buku yang telah diunggahnya

Pertemanan yang membentuk jaringan ini dapat saling mengetahui profil masing-masing pengguna di Facebook apa sebagai penjual (komunikator) dan pembeli (komunikan) atau sebatas audience (pemerhati buku) secara komunikasi interpersonal model diadik . Kesadaran antara penjual dan pembeli membentuk makna dalam kolom komentar dibawah postingan judul buku yang bersifat publik diketahui mutual friends atau melalui dialog percakapan chatting secara privacy.

\section{Kategori Judul Buku}

Dari hasil observasi dan hasil wawancara serta melalui bahan bacaan bukubuku yang dilakukan kedua peneliti didalam aplikasi Facebook mayoritas setiap penggunanya membangun jaringan dengan berteman atau membangun pertemanan yang sama-sama memiliki kesamaan hobi atau minat

Secara garis besar buku dibagi menjadi tiga kategori jenis yaitu : 1) buku baru (cetakan baru/teks ajar), 2)buku bekas (seken/tekspelajaran), 3) buku langka/antik (antique/rare).

Strategi postingan buku berupa foto atau video dalam menawarkan buku melalui judul, dan kesamaan hobby untuk mengkoleksi buku untuk diperjual-belikan Kembali menjadi satu upaya proses komunikasi bisnis yang dibangun bersama terkait tema atau judul buku yang terposting (terkadang ditambahkan oleh beberapa pengguna atau penjual buku dengan \#hastag)

Judul buku atau tema-tema buku yang kerap dicari dan kerapkali laku pada wall postingan Facebook penjual buku adalah buku tentang : Pramoedya Ananta Toer (PAT) kategori sastra, ideologi (buku kiri), militer, sejarah, agama, politik, ekonomi, hukum, sosial dan budaya serta buku bacaan hobi seperti : komik dan novel.

Berdasarkan hasil wawancara yang didapat dari 10 (sepuluh) pedagang dan kolektor/pembeli buku bahwa alasan buku ori kategori antik (asli) Pramoedya Ananta Toer (PAT) paling dicari ,paling diburu dan di hunting oleh para kolektor bahwa PAT adalah salah satu sastrawan Indonesia yang karyanya abadi lantaran judul Tetralogi Pulau Buru, merupakan karya yang membahas tentang roman sejarah Indonesia pra kemerdekaan diiringi judul buku "Bumi Manusia" juga, menjadi semakin terkenal, terutama di kalangan milenial karena dianggap banyak menginspirasi kaum segala usia.

Diketahui peneliti kembali dan diurutkan dari keminatannya setelah buku PAT yang menjadi incaran adalah bukubuku bernuansa dan bertema : "ideologi (buku kiri), militer, sejarah, agama, politik, ekonomi, sosial dan budaya serta buku bacaan hobi seperti : komik dan novel.

\section{Model Interaksi Komunikasi Bisnis Jual Beli} Buku di Facebook

Berdasarkan hasil observasi dan hasil wawancara yang dilakukan kekuatan proses komunikasi bisnis jual beli buku online di facebook dilakukan model pendekatan humanistik dengan penggunaan kepiawaian komunikasi antar pribadi dan komunikasi kelompok dengan mengutamakan interaksi :

\section{Keterbukaan (openness)/Kejujuran}

Dalam jual beli buku online ini kejujuran amatlah penting karena menjadi ujung tombak pemasarannya, sekali pesan akan kejujuran penjual buku yang disebarkan positif rekomendasi word of mouth marketing 
pesan yang diviralkan sesama pembeli buku juga akan berujung positif

Kejujuran disini menyangkut kepuasan pembeli akan: kondisi tentang buku (baru/seken/rusak/robek/buku ori atau buku bajakan/berat buku), harga buku, lokasi penjual buku,identitas penjual buku, biaya ongkos pengiriman buku. Kejujuran amat penting mengingat maraknya penipuan transaksi buku secara online sehingga antisipasi calon pembeli baru atau pelanggan baru meletakkan dalam hal kejujuran demi memuaskan pembeli.

\section{Menciptakan Chatting Dialog}

Penjual buku dan pembeli buku dalam sudut pandang komunikasi interpersonal memainkan sisi-sisi pandangan secara pendekatan humanistik, bahwa secara jelas kekuatan pesan adalah dalam chatting dialog antara penjual dan pembeli kedua membentuk makna-makna yang diciptakan masing-masing melalui proses komunikasi secara diadik. keterbukaan, empati, sikap mendukung, dan kualitaskualitas lain yang menciptakan interaksi serta bermakna jujur akan memuaskan pembeli dari setiap kategori-kategori buku yang dicari atau dihunting pelanggan atau calon pelanggannya.

Dari hasil temuan yang diketahui bahwa didalam chatting dialog secara interpersonal antara penjual dan pembeli buku memainkan emoticon atau sisipan yang menghibur satu sama lain sehingga membuat kesan transaksi menjadi sangat friendly dengan bahasa-bahasa informal terkesan jauh dari formal bagi penjual buku. Disini terjadi transaksi atau deal, saling tawar menawar yang berbuntut deal, dan saling bertukar informasi tawar menawar yang tidak ada kata kesepakatan harga antara penjual buku dan pembeli buku

\section{Bergabung dengan Komunitas Grup}

Bagi Penjual buku dan pembeli buku bergabung dalam grup merupakan urutan mendapatkan tempat atau space online (in group) untuk standby bagi pembeli buku menunggu postingan yang akan disebarkan oleh penjual buku dalam hal ini terdapat motivasi diantara penjual dan pembeli terhadap keminatan judul yang dipostingnya kemudian selanjutnya dikomentari dan berlanjut transaksi melalui kolom komentar atau melalui chatting dialog untuk mencapai kesepakatan sehingga tercapai tujuannya masing-masing

Pada segi interdependensi dalam konsep in group pembeli buku atau peminat buku sangat bergantung dari judul-judul buku yang ditawarkan oleh penjual buku, kemudian bergabung dengan teman didalam komunitaskomunitas grup

Menurut data yang didapatkan kedua peneliti alasannya lebih secure (aman) dikarenakan anggota-anggota penggunanya yang tergabung telah tersortir dan terpilih oleh admin pengelola pada masing-masing grup jual beli buku yang ada sehingga meminimalisir terjadinya penipuan online dan identitas palsu dan hal-hal yang tidak diinginkan , dikarenakan disetiap grup memiliki aturan dan ketentuan yang berlaku serta wajib dipatuhi secara bersama-sama

\section{KESIMPULAN}

Simpulan yang didapatkan kedua peneliti dalam penelitian ini adalah: bahwa facebook tidak hanya berfungsi sebagai media promosi iklan jual beli buku akan tetapi memiliki peranan yang lebih besar lagi menciptakan jejaring dan pasar jual beli buku online yang lebih luas lagi. Adapun terdapat 3 (tiga) kategori besar buku-buku yang bisa diperjualbelikan Kembali yang mana kategori buku antik atau buku PAT menjadi incaran pembeli atau kolektor buku. Teman bersama (mutual friends) menjadi upaya alat atau tool deteksi identitas pengguna facebook dalam eksistensinya sebagai penjual dan pembeli buku untuk memastikan identitas masingmasing.Ada 3 (tiga) kekuatan dalam 
model interaksi jual beli buku di Facebook, yaitu: 1) Kejujuran, 2) Kepiawaian bercakap (via chatting dialog) menciptakan ruang dialog dibaluti dengan keterbukaan empati, sikap yang positif, merasa equality dan friendly-ship dalam jaringan pertemanan, 3)Bergabung kedalam group buku menjadi upaya untuk menciptakan pasar dengan menambah pertemanan yang lebih maksimal lagi

\section{DAFTAR PUSTAKA}

Bahfiarti, T. (2012). Buku Ajar DasarDasar Teori Komunikasi. 9.

Evans, D. (2010). Social Media Marketing: The Next Generation of Business Engagement. http://www.amazon.com/dp/047063 4030

Fatimah, \& Nuryaningsih. (2018). Buku Ajar Buku Ajar.

Gemilang, R. D. A. (2011). Peran Facebook sebagai Media Komunikasi Bisnis Online ( Studi Deskriptif Kualitatif Peran Facebook sebagai Media Komunikasi Bisnis Online ). i-vii + 117.

Hasbiansyah, O. (2008). Pendekatan Fenomenologi: Pengantar Praktik Penelitian dalam Ilmu Sosial dan Komunikasi. Mediator: Jurnal Komunikasi, $\quad 9(1), \quad$ 163-180. https://doi.org/10.29313/mediator.v 9i1.1146

Kertamukti, R. (2013). Strategi Komunikasi Antarpribadi Dosen Dan Mahasiswa Dalam Pengembangan Jiwa Kreatif. Profetik: Jurnal Komunikasi, 6(2), 27-35. http://ejournal.uinsuka.ac.id/isoshum/profetik/article/ view/1167/1077
Levy, J. R. (2010). Facebook marketing.

Pandjaitan, D. R. H. (2016). Komunikasi Bisnis. II(1), 53-64. http://repository.lppm.unila.ac.id/23 00/

Raco, J. (2018). Metode penelitian kualitatif: jenis, karakteristik dan keunggulannya. https://doi.org/10.31219/osf.io/mfzu j

Susanti, E., \& Kholisoh, N. (2018). KONSTRUKSI MAKNA KUALITAS HIDUP SEHAT (Studi Fenomenologi pada Anggota Komunitas Herbalife Klub Sehat Ersanddi Jakarta). LUGAS Jurnal Komunikasi, 2(1), 1-12. https://doi.org/10.31334/j1.v2i1.117

Tutiasri, R. P. (2016). Komunikasi Dalam Komunikasi Kelompok. CHANNEL: Jurnal Komunikasi, 4(1), 81-90. https://doi.org/10.12928/channel.v4 i1.4208 